\title{
First genotoxicity study of Paraná river water from Argentina using cells from the clam Corbicula fluminea (Veneroida Corbiculidae) and Chinese hamster (Cricetulus griseus Rodentia, Cricetidae) K1 cells in the comet assay
}

\author{
Jacqueline D. Caffetti ${ }^{1}$, Mário S. Mantovani ${ }^{2}$, María C. Pastori ${ }^{1}$ and Alberto S. Fenocchio ${ }^{1}$ \\ ${ }^{1}$ Departamento de Genética, Universidad Nacional de Misiones, Posadas, Misiones, Argentina. \\ ${ }^{2}$ Departamento de Biologia Geral, Universidade Estadual de Londrina, Londrina, PR, Brazil.
}

\begin{abstract}
High concentrations of xenobiotics from urban and industrial wastes have contributed to the contamination of many aquatic environments. We used the comet assay to evaluate the genotoxic potential of water collected from the River Paraná, which receives a great deal of waste, at three points (Puerto Piray, Eldorado and Montecarlo) in the Misiones Province of Argentina. The in vivo comet assay used 40 freshwater clams (Corbicula fluminea) while the in vitro comet assay used Chinese hamster (Cricetulus griseus) $\mathrm{K} 1$ cell (CHO-K1) cultures with the mutagen ethyl methanesulfonate (EMS) as the positive control and phosphate buffered saline (PBS) as the negative control. Both assays showed statistically significant differences between the three sampling sites in relation to the negative control, the results of this preliminary study indicating that at these three sites water from the Paraná River presents genotoxic potential.
\end{abstract}

Key words: biomonitoring, Comet assay, Corbícula fluminea, CHO-K1 cells, genotoxicity, Paraná river.

Received: May 25, 2007; Accepted: October 11, 2007.

\section{Introduction}

The high concentrations of xenobiotics from urban and industrial wastes have contributed to the contamination of aquatic environments (Al Sabti and Metcalfe, 1995). These substances could be potentially genotoxic or mutagenic and could be directly and/or indirectly accumulated by the aquatic organisms causing DNA damage (Sasaki et al., 1997; Lee and Steinert, 2003). The evaluation of genotoxicity through the response of sentinel organisms (bioindicators) to the pollutants is an important tool for the control of contamination in aquatic environments (Rajaguru et al., 2002). Bivalve mollusks are very useful as bioindicators, since they are sedentary filter feeders and have the capacity to bioaccumulate contaminants (LópezBarea and Pueyo, 1998; Gielazyn et al., 2003; Bolognesi et al., 2004). The Asian clam Corbicula fluminea is an exotic freshwater bivalve introduced into Argentina around 1970 and is now widely distributed along the Paraná River and an important component of the benthic community. These clams are an optimal in vivo biomonitor for aquatic envi-

Send correspondence to Jacqueline Diana Caffetti. Laboratorio de Citogenética, Departamento de Genética, Félix de Azara 1552, 3300 Posadas, Misiones, Argentina. E-mail: jacqui_caffetti@ yahoo.com.ar. ronments due to their high filtration rates, ease of collection and the fact that their laboratory maintenance is simple (Cataldo et al., 2001). The bioaccumulation capacity of $C$. fluminea in bioassays has been reported by several workers (Bilos et al., 1998; Rigonato et al., 2005). Furthermore, a study of the lower Paraná River showed a high mortality of young $C$. fluminea in regions contaminated with urban and industrial effluents, suggesting that this bivalve could be a reliable indicator of water quality (Cataldo et al., 2001). Xenobiotic testing can also be accomplished in vitro in the laboratory using well established cell lines such as Chinese hamster (Cricetulus griseus) K1 cell (CHO-K1) cultures (Takahashi, 2003; Bellini et al., 2006), which provide an excellent biological model for evaluating potential genotoxicity in polluted water (Matsumoto et al., 2003). Single cell gel electrophoresis (SCGE), commonly called the comet assay, is capable of detecting DNA damage in practically all eukaryotic cells (Kassie et al., 2000; Tice et al., 2000) and is widely used for pollutant biomonitoring in aquatic environments (Sasaki et al., 1997; Tice et al., 2000; Avishai et al., 2002; Lemos et al., 2005).

Rivers in Argentina have shown a high level pollution, this being especially true for the Paraná River, one of the largest rivers in the world, which has a large part of its watershed in Brazil. The Paraná River collects a variety of 
wastes and pollutants, including agrochemicals and industrial and urban effluents, from its headwaters and carries these into Argentina (Foguelmen and Gonzalez Urda, 1994).

During the study described in this paper we used the in vivo comet assay with the bivalve mollusk $C$. fluminea and the in vitro comet assay with CHO-K1 cells to carried out the first evaluation of the potential genotoxicity of Paraná river water from three different localities in the Misiones province of Argentina.

\section{Materials and Methods}

\section{Water samples}

Water samples were collected along the Paraná River from north to south at the following three sites in Misiones province Argentina: Puerto Piray (port Piray) at km 1800 $\left(26^{\circ} 28^{\prime} \mathrm{S}, 54^{\circ} 42^{\prime} \mathrm{W}\right)$, near the discharge site of a paper and pulp mill; Eldorado city at $\mathrm{km} 1806\left(26^{\circ} 24^{\prime} \mathrm{S}, 54^{\circ} 38^{\prime} \mathrm{W}\right)$, $6 \mathrm{~km}$ upstream (north) of Puerto Piray; and Montecarlo city at $\mathrm{km} 1787\left(26^{\circ} 34^{\prime} \mathrm{S}, 54^{\circ} 47^{\prime} \mathrm{W}\right), 13 \mathrm{~km}$ downstream (south) of Puerto Piray. Quilometers 1787, 1800 and 1806 refer to the mouth of the Paraná river. The water was placed in appropriate glass bottles and transported to the laboratory at the General Biology Department at the Universidade Estadual de Londrina, Paraná, Brazil within 12 h, during which time the temperature of the samples did not rise above $20^{\circ} \mathrm{C}$.

\section{Bioassay procedures}

For the in vivo clam bioassay we collected 40 Corbicula fluminea Müller 1774 (Veneroida Corbiculidae) freshwater clams from the riverbed of the River Cambé near the town of Londrina in the Brazilian state of Paraná, and transported to the laboratory of the Universidade Estadual de Londrina where they were acclimatized and detoxified for 30 days in $120 \mathrm{~L}$ of constantly aerated water taken from a well at Universidade Estadual de Londrina and contained in a glass aquarium $(80 \mathrm{~cm}$ long $28 \mathrm{~cm}$ wide $40 \mathrm{~cm}$ high), the volume being kept constant by the addition of well water and the temperature during this time ranging from $18{ }^{\circ} \mathrm{C}$ to $20^{\circ} \mathrm{C}$. For each river water sample, a group of 10 clams was placed for $72 \mathrm{~h}$ in 2 litres of the aerated river water sample contained in a glass aquarium $(30 \mathrm{~cm}$ long $20 \mathrm{~cm}$ wide $18 \mathrm{~cm} \mathrm{high)} \mathrm{at} 18{ }^{\circ} \mathrm{C}$ to $20^{\circ} \mathrm{C}$, a further 10 clams being maintained, under the same conditions, in well water as a negative control. After $72 \mathrm{~h}$ sterile $1 \mathrm{~mL}$ syringes were used to collect haemolymph from the posterior adductor muscle of each clam, the haemolymph being placed in Eppendorf tubes and centrifuged for $5 \mathrm{~min}$ at $2000 \mathrm{rpm}$ to pellet the cells, which were subsequently resuspended in the same supernatant for use in the comet assay.
For the in vitro $\mathrm{CHO}-\mathrm{K} 1$ assay the cells were grown in a 1:1 (v/v) mixture of HAM's F10 medium and Dulbecco's Modified Eagle's medium (HAM F10:DMEM) supplemented with $10 \%(\mathrm{v} / \mathrm{v})$ fetal calf serum and $0.1 \%$ $(\mathrm{v} / \mathrm{v})$ antibiotic-antimitotic solution and buffered to $\mathrm{pH}$ 7.2. Cultures were incubated at $37^{\circ} \mathrm{C}$ for $46 \mathrm{~h}$ and then separated from the culture medium by centrifugation for $10 \mathrm{~min}$ at $1250 \mathrm{rpm}$ and placed in $30 \mathrm{~mL}$ of river water to which $10 \mathrm{~mL}$ of the above culture medium was added to give a 3:1 dilution. This procedure was repeated for the water sample from each site and $5 \mathrm{~mL}$ aliquots distributed in culture flasks, three for each water sample. For the negative control CHO-K1 cells were produced in the same way as above, except that the cells were placed in $40 \mathrm{~mL}$ of $3: 1(\mathrm{v} / \mathrm{v})$ phosphate buffered saline:culture medium, $5 \mathrm{~mL}$ aliquots of this cell suspension being distributed in three separate flasks. The same procedure was adopted for the positive control, except that the cells were placed in $40 \mathrm{~mL}$ of culture medium containing the mutagen ethyl methanesulfonate (EMS, CAS: 62-50-0, Sigma) at a final concentration of $150 \mu \mathrm{g} \mathrm{mL}^{-1}$. In all cases, the CHO-K1 cells were incubated at $37^{\circ} \mathrm{C}$ for a further $2 \mathrm{~h}$ and then washed twice with $5 \mathrm{~mL}$ of PBS, harvested from the culture flasks with $0.5 \mathrm{~mL}$ of a $0,025 \%$ trypsin solution, centrifuged for $10 \mathrm{~min}$ at $1250 \mathrm{RPM}$ and re-suspended in $1 \mathrm{~mL}$ of the same culture medium for use in the comet assay. All chemicals were of at least analytical quality. The HAM F10 culture medium was bought from Gibco BRL and the D-Mem culture medium from Gibco BRL.

\section{Comet assay}

For each comet assay $20 \mu \mathrm{L}$ of cell suspension (resuspended haemolymph pellet or CHO-K1 cells) was gently homogenized with $120 \mu \mathrm{L}$ of $0.5 \%$ (w/v) low melting point (LPM) agarose (Sigma) at $37^{\circ} \mathrm{C}$ and dropped onto microscope slides coated with solidified $1.5 \%(\mathrm{w} / \mathrm{v})$ normalmelting point (NPM) agarose (Sigma). A coverslip was added and the slide allowed to stand at $4{ }^{\circ} \mathrm{C}$ for $20 \mathrm{~min}$, after which the coverslip was removed and the comet assay carried out according to the method of Speit and Hartmann (1999), with the following slight modifications: $1 \mathrm{~h}$ of lysis in a solution containing $1 \mathrm{~mL}$ of Triton X-100, $10 \mathrm{~mL}$ dimethyl sulfoxide (DMSO) and $89 \mathrm{~mL}$ of lysis stock solution (containing: $2.5 \mathrm{M} \mathrm{NaCl} ; 100 \mathrm{mM}$ EDTA, $10 \mathrm{mM}$ Tris and $1 \%(\mathrm{w} / \mathrm{v})$ sodium $\mathrm{N}$-Lauryl sarcosinate, $\mathrm{pH} 10)$ at $4{ }^{\circ} \mathrm{C}$ in the dark, followed by 20 min denaturation in electrophoresis buffer (containing: $300 \mathrm{mM} \mathrm{NaOH}$ and $1 \mathrm{mM}$ EDTA at $\mathrm{pH}>13$, prepared from a stock solution of $10 \mathrm{~N} \mathrm{NaOH}$ and $200 \mathrm{mM}$ EDTA at $\mathrm{pH} \mathrm{10}$ ) and electrophoresis for $20 \mathrm{~min}$ at $25 \mathrm{~V}$ and $300 \mathrm{~mA}$ followed by neutralization, fixation in ethanol and staining with $0.002 \mathrm{mg} \mathrm{mL}^{-1}$ ethidium bromide. The cells were examined at $400 \mathrm{X}$ with a fluorescence microscope using a $420 \mathrm{~nm}$ to $490 \mathrm{~nm}$ excitation fil- 
ter and a $520 \mathrm{~nm}$ emission filter. One hundred cells were analyzed per sample (treatments and controls) and were classified according to the size of the comet tail: class 0 , no tailed; class 1, a short tail smaller than the diameter of the nucleoid; class 2, a tail length 1 to 2 times the diameter of the nucleoid; class 3, a tail length more than twice the nucleoid diameter (see Figure 1 a to d). For each treatment the comet scores were calculated by summing the number of cells in each class and then multiplying the total by the class value ( 0 to 3$)$. The slides were all scored blind by the same person.

\section{Statistical analysis}

The potential genotoxicity of the water samples were evaluated using the Student's t-test at the 5\% significance level, the Instat GraphPad Software V2.01 Copyright 1990-1993 Dr. Cipolla-Neto, Univ. de São Paulo being used to perform the statistical analysis.

\section{Results and Discussion}

We used in vivo and in vitro comet assays to evaluate water samples from three sites on the Paraná River and, in both assays, found an increase in the number of cells damaged in relation to the negative control (Table 1, Figure 2 a, b). Water from the Puerto Piray site showed the highest values for all three comet classes. Furthermore, in the in vivo assay, but not the in vitro assay, the differences between the Puerto Piray site and the more northern site at Eldorado and the more southerly site at Montecarlo were statistically significant (Figure $2 \mathrm{a}, \mathrm{b}$ ). Our results showed that the damage detected by the comet assay was highest at Puerto Piray (Table 1), where the paper and pulp mill effluents are discharged and the concentration of xenobiotics may have been higher. At Eldorado, upstream of Puerto Piray, xenobiotics released by the mill would have been more diluted, which would also be true for the downstream site at Montecarlo due to the increased volume of water at this site. In

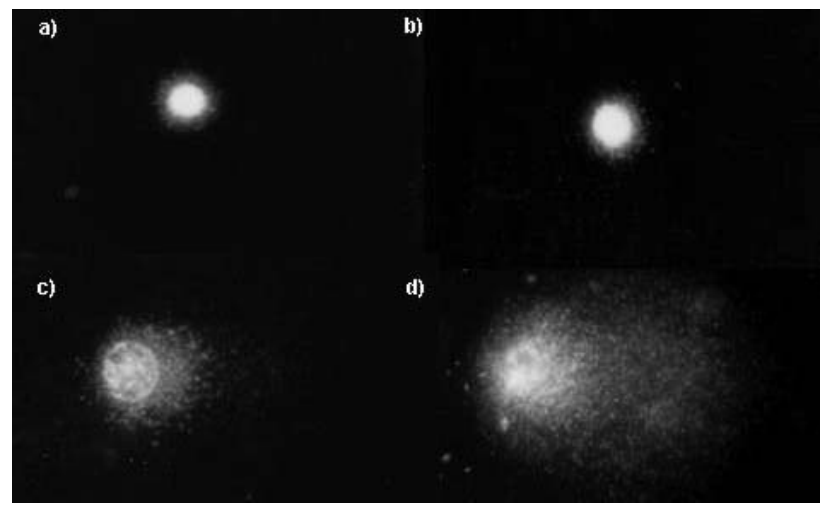

Figure 1 - Comets of Corbicula fluminea (a) class 0 (b) class 1 hemocytes from hemolymph. Comets of Chinese hamster K1 (CHO-K1) cells c) class 2 , d) class 3 . fact, our results show that the least amount of damage detected by the comet test occurred with water from the Montecarlo site (Table 1). Other studies have reported that pulp and paper mill wastes from show high mutagenic potential (Houk, 1992; Claxton et al., 1998), however, we have not yet identified the chemical compounds that are

Table 1 - Comet cell damaged scores obtained for Corbicula fluminea hemolymph cells and Chinese hamster K1 (CHO-K1) cells. Scores were calculated by summing the number of cells in each class and then multiplying by the class value ( 0 to 3 ). The negative control was well water for C. fluminea and phosphate buffered saline for the CHO-K1 cells. The positive control was $150 \mu \mathrm{g} \mathrm{mL}^{-1}$ of the mutagen ethyl methanesulfonate.

\begin{tabular}{lcc}
\hline Sample & \multicolumn{2}{c}{ Comet score } \\
\cline { 2 - 3 } & $\begin{array}{c}\text { C. fluminea } \\
\text { in vivo assay }\end{array}$ & $\begin{array}{c}\text { CHO-K1 cell } \\
\text { in vitro assay }\end{array}$ \\
\hline Eldorado water & 54.20 & 60 \\
Puerto Piray water & 78.32 & 77.2 \\
Montecarlo water & 50.57 & 55.7 \\
Negative control & 21.11 & 25.7 \\
Positive control & & 170.4 \\
\hline
\end{tabular}

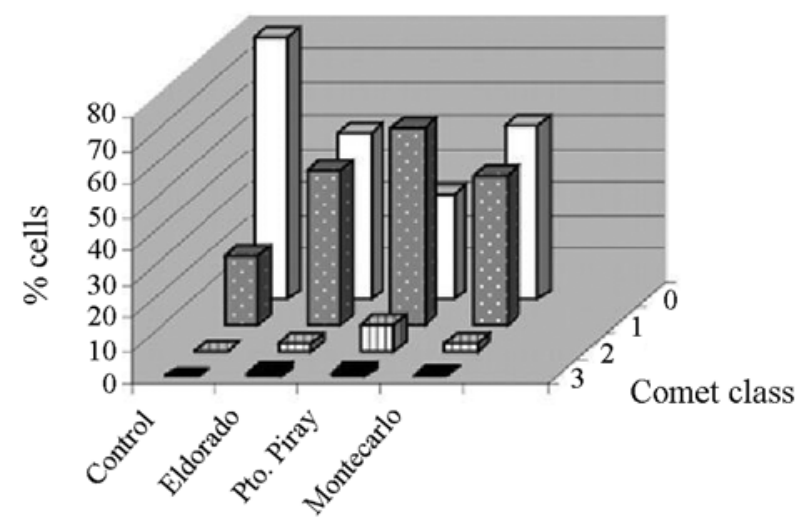

Treatments

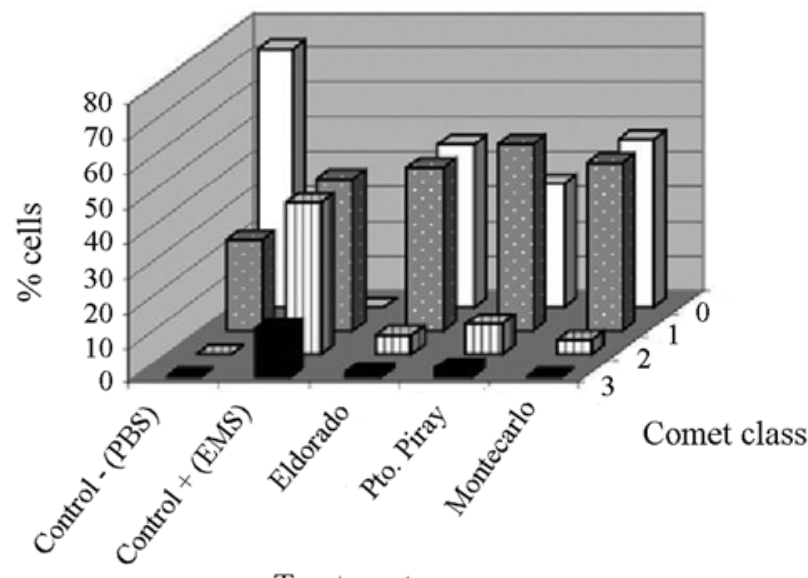

Treatments

Figure 2 - Levels of DNA damage in (a) Corbicula fluminea hemolymph cells and (b) Chinese hamster K1 (CHO-K1) cells after treatment with Paraná River water. 
dissolved in the Parana River water at the three sample points.

Differences between the in vivo and in vitro bioassays may have been because in the in vivo assays the toxic compounds could be metabolized by the organisms as a whole, while in the in vitro assays the cultured cells were directly exposed to damage. Alternatively, the differences could also have been due to differences in the background level of DNA damage in the distinct cell types used in each assay that have different mechanisms of DNA incorporation, accumulation and repair (Monteith and Vanstone, 1995; Jha, 2004). In spite of this, the similarity between the in vivo and in vitro assays is interesting, with the greater part of the DNA strand breaks being represented by comet class 1 . In the in vivo test class 1 comets were most frequent for cells treated with Puerto Piray water while class 0 comets were most frequent for cells treated with river water from the other sites. Comparing these results with those for the in vitro assays suggests that whole organisms can process and minimize the effects of contaminants more efficiently that cells in culture (Table 1, Figure 2 a). Our results indicate that $C$. fluminea and $\mathrm{CHO} \mathrm{k} 1$ cells are good models for biomonitoring fresh water environments using the comet assay, supporting the work of other authors (Matsumoto et al., 2003; Rigonato et al., 2005). The high comet scores, and hence damage, in the cells treated with river water as compared to the negative control could be attributed to the action of industrial and urban discharges carried by the Paraná river water. Taking into account scarcity of available information for the region evaluated our results indicate the importance of monitoring the water in the Paraná river to evaluate the nature of the pollutants responsible for the relatively high comet scores seen in our study. A multidisciplinary approach and good chemical characterization of the xenobiotics content of the water may well shed light to evaluate its potential genotoxicity.

\section{Acknowledgments}

The authors thank the Universidade Estadual de Londrina (Centro de Ciências Biológicas), Universidad Nacional de Misiones (Facultad de Ciencias Exactas, Químicas y Naturales), Secretaría de Políticas Universitarias, Comité Ejecutivo de Desarrollo e Innovación Tecnológica (Provincia de Misiones), CONICET (Argentina), Universidad Nacional de Córdoba (Doctorado en Ciencias Biológicas) and Mr. M. Ledesma.

\section{References}

Al Sabti K and Metcalfe CD (1995) Fish micronuclei for assessing genotoxicity in water. Mutat Res 343:121-135.

Avishai N, Rabinowitz C, Moiseeva E and Rinkevich B (2002) Genotoxicity of the Kishon River, Israel: The application of an in vitro cellular assay. Mutat Res 518:21-37.
Bellini MF, Angeli JPF, Matuo R, Terezan AP, Ribeiro LR and Mantovani MS (2006) Antigenotoxicity of Agaricus blazei mushroom organic and aqueous extracts in chromosomal aberration and cytokinesis block micronucleous assays in CHO-K1 and HTC cells. Toxicol in vitro 20:355-360.

Bilos C, Colombo JC and Rodriguez Presa MJ (1998) Trace metals in suspended particles, sediments and Asiatic clams (Corbicula fluminea) of the Rio de la Plata Estuary, Argentina. Environ Pollut 99:1-11.

Bolognesi C, Buschini A, Branchi E, Carboni P, Furlini M, Martino A, Monteverde M, Poli P and Rossi C (2004) Comet and micronucleus assays in zebra mussel cells for genotoxicity assessment of surface drinking water treated with three different disinfectants. Sci Total Environ 333:127-136.

Cataldo D, Colombo JC, Boltovskoy D, Bilos C and Landoni P (2001) Environmental toxicity assessment in the Paraná river delta (Argentina): Simultaneous evaluation of selected pollutants and mortality rates of Corbicula fluminea (Bivalvia) early juveniles. Environ Pollut 112:379-389.

Claxton LD, Houk VS and Hughes TJ (1998) Genotoxicity of industrial wastes and effluents. Mutat Res 410:237-243.

Foguelmen D and Gonzalez Urda E (1994) Ecología y Medio Ambiente: El Agua en Argentina.1 era edición. CONICET, Buenos Aires, 256 pp.

Gielazyn ML, Ringwood AH, Piegorsch WW and Stancyk SE (2003) Detection of oxidative damage in isolated marine bivalve hemocytes using the comet assay and formamidopyrimidine glycosylase (Fpg). Mutat Res 542:15-22.

Houk, VS (1992) The genotoxicity of industrial wastes and effluents. Mutat Res 277:91-138.

Jha AN (2004) Genotoxicological studies in aquatic organisms: An overview. Mutat Res 552:1-17.

Kassie F, Parzefall W and Knasmüller S (2000) Single cell gel electrophoresis assay: A new technique for human biomonitoring studies. Mutat Res 463:13-31.

Lee RF and Steinert F (2003) Use of the single cell gel electrophoresis/comet assay for detecting DNA damage in aquatic (marine and freshwater) animals. Mutat Res 544:43-64.

Lemos NG, Dias AL, Silva-Souza AT and Mantovani MS (2005) Evaluation of environmental waters using the comet assay in Tilapia rendalli. Environ Toxicol Pharmacol 19:197-201.

Lopez-Barea J and Pueyo C (1998) Mutagen content and metabolic activation of promutagens by molluscs as biomarkers of marine pollution. Mutat Res 399:3-15.

Matsumoto ST, Mantovani MS, Mallaguti MI and Marin-Morales MA (2003) Investigation of the genotoxic potential of the waters of a river receiving tannery effluents by means of the in vitro comet assay. Cytologia 68:395-401.

Monteith DK and Vanstone J (1995) Comparison of the microgel electrophoresis assay and other assays for genotoxicity in the detection of DNA damage. Mutat Res 345:97-103.

Rajaguru P, Vidya L, Baskarasethupathi B, Kumar PA, Palanival $\mathrm{M}$ and Kalaiselvi K (2002) Genotoxicity evaluation of pollution ground water in human peripheral blood lymphocytes using the comet assay. Mutat Res 517:29-37.

Rigonato J, Mantovani MS and Jordão BQ (2005) Comet assay comparison of different Corbicula fluminea (Mollusca) tissues for the detection of genotoxicity. Genet Mol Biol 28:464-468.

Sasaki YF, Izumiyama F, Nishidate E, Ishibashi S, Tsuda S, Matsusaka N, Asano N, Saotome A, Sofuni E and Hayashi 
M (1997) Detection of genotoxicity of polluted sea water using shellfish and the alkaline single-cell gel electrophoresis (SCE) assay: A preliminary study. Mutat Res 393:133-139.

Speit G and Hartmann A (1999) The comet assay (single-cell gel test): A sensitive genotoxicity test for the detection of DNA damage and repair. In: Henderson DS (ed) Methods in Molecular Biology. v. 113. DNA Repair Protocols: Eukaryotic systems. Humana Press, Totowa, pp 203-212.
Takahashi CS (2003) Testes citogenéticos in vitro e aneuploidia. In: Ribeiro LR, Salvadori DMF and Marques EK (eds) Mutagênese Ambiental. ULBRA, Canoas, pp 151-172.

Tice RR, Agurell E, Anderson D, Burlinson B, Hartmann A, Kobayashi H, Miyamae Y, Rojas E, Ryu JC and Sasaki YF (2000) Single cell gel/Comet assay: Guidelines for in vitro and in vivo genetic toxicology testing. Environ Mol Mutagen 35:206-221.

Associate Editor: Catarina S. Takahashi

License information: This is an open-access article distributed under the terms of the Creative Commons Attribution License, which permits unrestricted use, distribution, and reproduction in any medium, provided the original work is properly cited. 